\title{
URBAN NOW: CITY LIFE IN CONGO
}

\author{
Sammy Baloji (1) and Filip De Boeck (2) \\ (1) Photographer, Belgium, Democratic Republic of the Congo \\ (2) Institute for Anthropological Research in Africa, KULeuven, Belgium
}

In ongoing discussions about the nature of the African city, architects, urban planners, sociologists, anthropologists, demographers and others devote much attention to the built form, and more generally to the city's material infrastructure. Architecture has become a central issue in western discourses and reflections on how to plan, engineer, sanitize and transform the urban site and its public spaces. Mirroring that discourse, architecture has also started to occupy an increasingly important place in the attempts to come to terms with the specificities of the African urbanscape and to imagine new urban paradigms for the African city of the future. Very often these new urban futures manifest themselves as 'cities yet to come' ${ }^{\text {s }}$ in the form of billboards and advertisements. Through an aesthetic display of modernization as spectacle, and inspired by urban models from Dubai and other recent urban hot spots from the Global South, these images foster new dreams and hopes, even though the new city they propose invariably gives rise to new geographies of exclusion, as such a city often takes the form of gated communities and luxury satellite towns for an often still rather hypo- thetical local upper middle class.

In sharp contrast to these - often violentneoliberal re-codings of earlier colonialist modernities, the current infrastructure of Kinshasa, the capital of the Democratic Republic of Congo, is of a rather different kind. The built colonial legacy has often fallen into disrepair. Its functioning is punctuated by constant breakdown, and the city is replete with disconnected infrastructural fragments, figments, reminders and echoes of a former modernity that continues to exist in a shattered form, but no longer has the content that originally went with it. These fragments are embedded in other historical rhythms and temporalities, in entirely different layers of infrastructure, land ownership rights and social networks. Failing material infrastructures and an economy of scarcity physically delineate the limits of the possible in the city. At the same time however, they also generate other possibilities and enable the creation of new social spaces by means of which breakdown and exclusion are bypassed and overcome.

In a collaborative effort between anthropology and photography, a project that has

Simone, A., 2004. For the City Yet to Come. Changing African Life in Four Cities. Durham: Duke University Press. 
resulted in a book and an exhibition ${ }^{2}$, the present authors, visual artist Sammy Baloji and anthropologist Filip De Boeck reflect on these various - different but simultaneous - narratives of urban place-making. In this joint work we offer a visual study of elements that defy verbal narration: the city's affective landscapes and moods. As such we consider changes in how cities and territories are imagined by different kinds of people in the DRC today.

Essentially, our ethnographic, photographic and filmic exploration of the city's scape offers an investigation into the qualities of the 'hole'. One could say that, today, the notion of the hole (libulu in Lingala, the lingua franca in large parts of Congo) fully captures the essence of the city's material quality. It defines the generic form of Congo's postcolonial urban infrastructure. Indeed, the surface of the Congolese city is pockmarked with potholes, while unstoppable erosion points constantly eat away at the urban tissue. Similarly, the surface of the Congolese landscape is disfigured by artisanal mining holes and the holes of (often unmarked) graves. In fact the concept of the 'hole' has become a kind of meta-concept that people use to reflect upon the material degradation of the city's colonial modernist infrastructure and to rework the closures and often dismal quality of the social life that has followed the material ruination of the colonial city. What our work reflects upon, then, is basically the question of how this 'reworking' takes place, and how in terms of the experience of Congolese urban residents, this postcolonial hole is filled. What possible answers does urban Congo offer in response to the challenge posed by the hole? If the city has transformed into a hole, how can this hole be 'illuminated' to become the something else that enables living, and living together in the city? The notion of living together can only exist where the whole, the assemblage is not fully formed and is not yet closed. Living together always implies a contestation of how a social body, a collective, completes itself - it is a process that is never completely closed, summed up or fully identical with itself.

As family, kinship and neighbourhood solidarities are often stretched to the limit, and residents search, sometimes desperately, for a viable experience of being together, we have tried to understand what new forms are emerging, and how to understand these new forms. What is investigated here are the closures and openings through which this living together in the city is made possible or is rendered impossible. In this sense, our collaborative effort can be read as an attempt to discover where and how people stitch together their lacks and losses and 'suture' the folds, gaps and holes of the city. Sutures here suggest the possibility of closing wounds, generating realignments and opening up alternatives, thereby pointing to new kinds of creativity with (spatial and temporal) beginnings, and new forms of interactivity and conviviality. We investigate these gaps and sutures by means of a number of urban acupunctures, in other words, investigations of specific sites within (and often beyond) the city of Kinshasa - particular buildings, horticultural sites and fields in the city,

2 De Boeck, F. \& S.Baloji, 20r6, Suturing the City. Living Together in Congo's Urban Worlds. London: Autograph ABP. Our exhibition Urban Now. City Life in Congo opened in WIELS in 2016, and subsequently traveled to Open Society (New York, 2016), The Power Plant (2017), and Galeria da India (Lisbon, 20I8). 
specific graveyards, mountains, potholes, new city extensions, and so on - into which we insert our analytical needle, the instruments of pen and photographic lens, in order to understand what happens in all of these places that form important, though sometimes materially barely visible, nodes within the city. These are sites where the city switches on and off, where quickenings and thickenings of goods, people are generated and the various lines of connec- tion between them become visible.

In our combination of two ways of 'seeing' that bring together ethnography and photography, we have attempted to develop a form of 'photo writing' to delve into the realities of everyday urban living and the different kinds of - colonial and postcolonial - histories that it reflects and sometimes transcends in its attempt to construct more tangible and liveable, inhabitable urban lives and futures.

Filip De Boeck is a Belgian anthropologist, writer, filmmaker and curator. He holds a

Professorship at the Institute for Anthropological Research in Africa, a research center of the University of Leuven.

Sammy Baloji is a photographer and visual artist from the Democratic Republic of the Congo. He currently works between Lubumbashi and Brussels. The recipient of many awards, his work has been exhibited in important museums and artistic venues across the world.

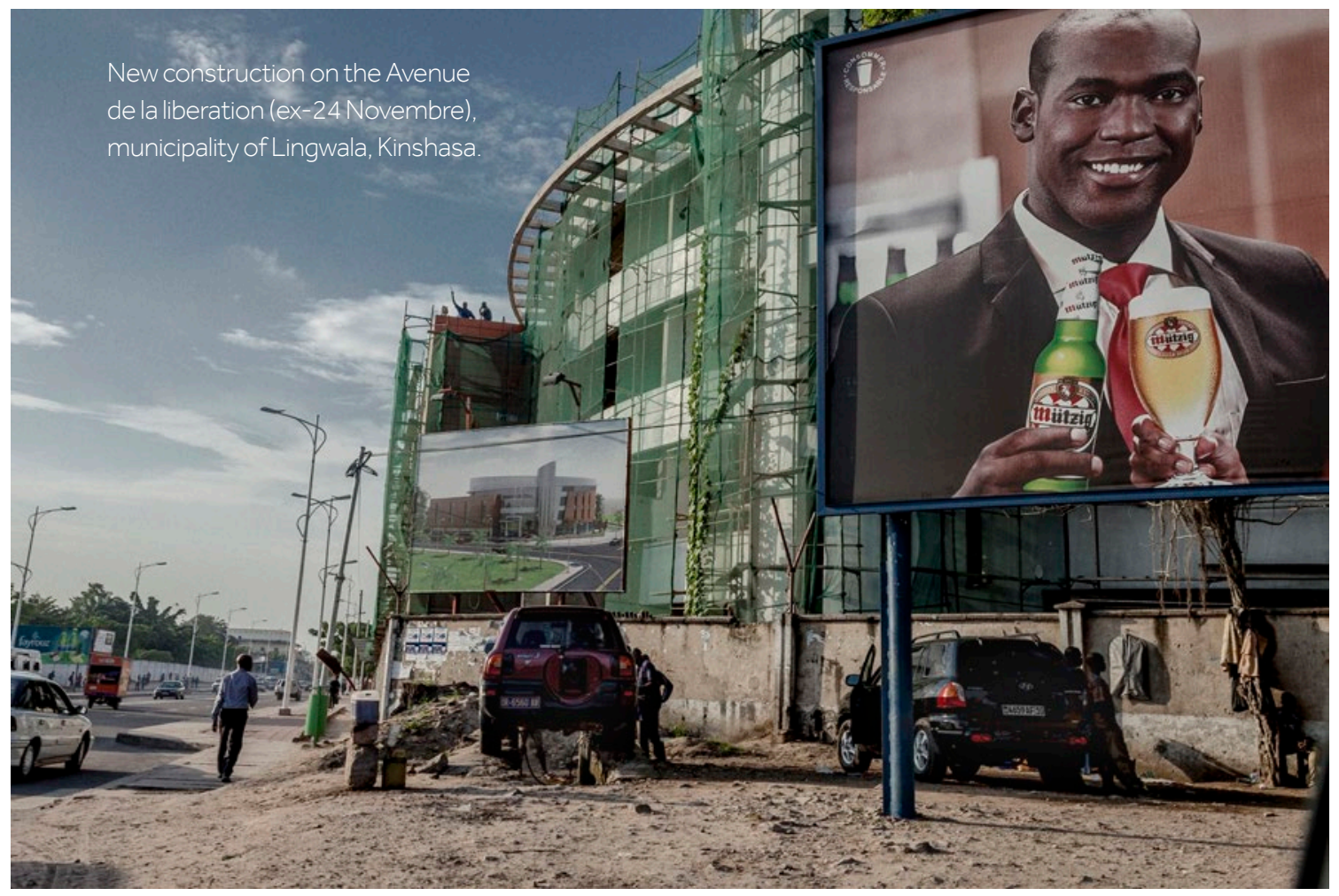




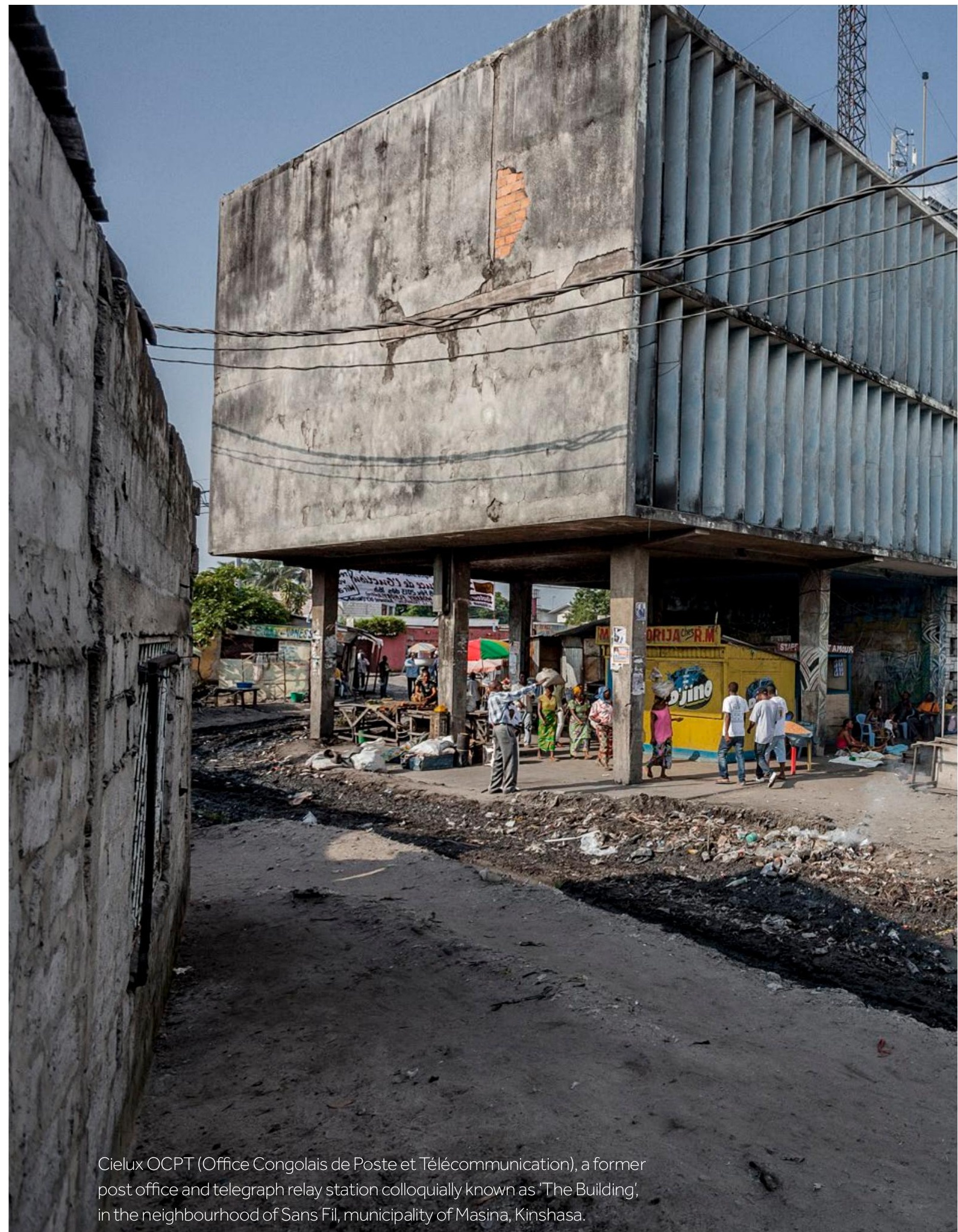




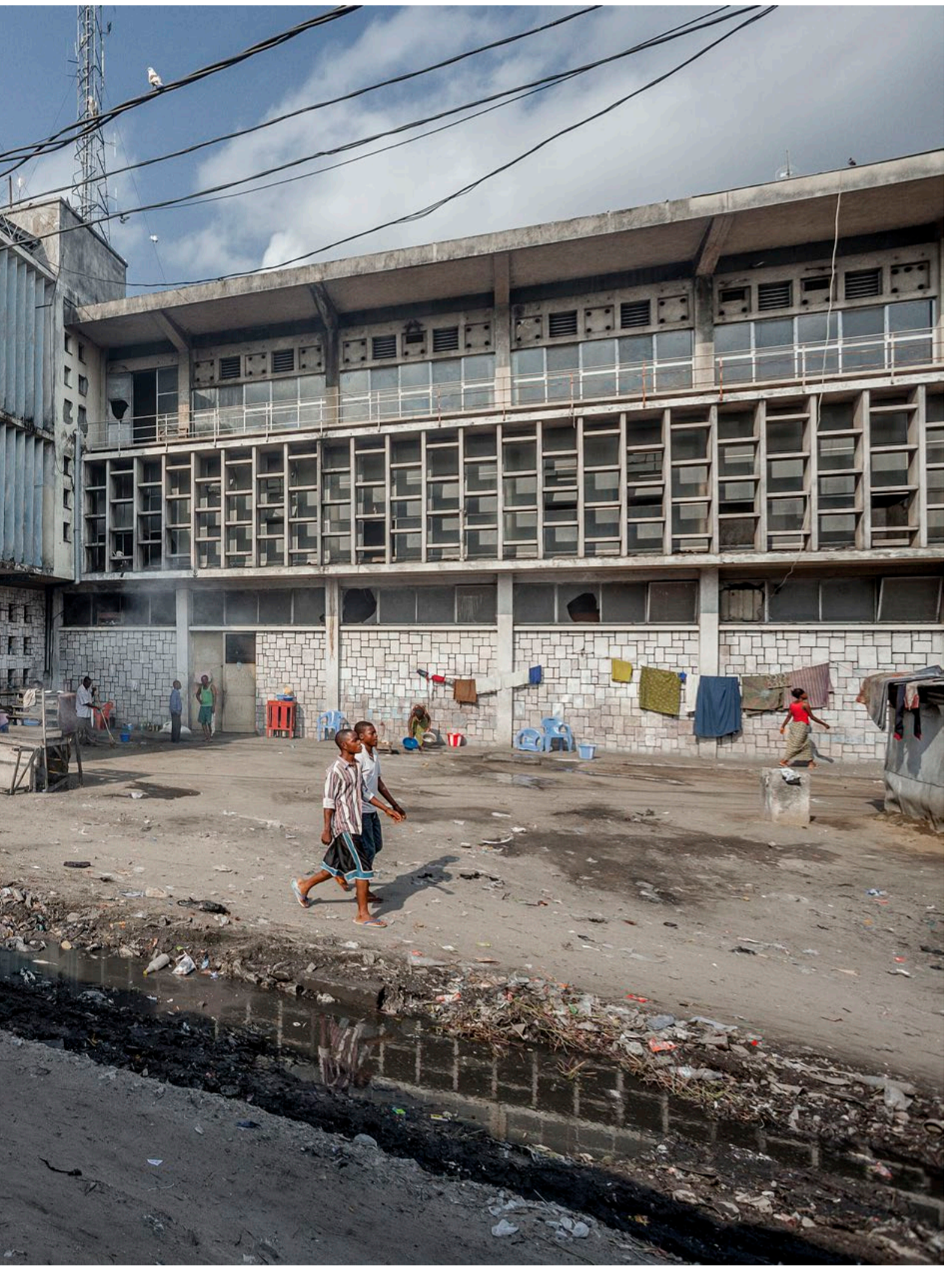




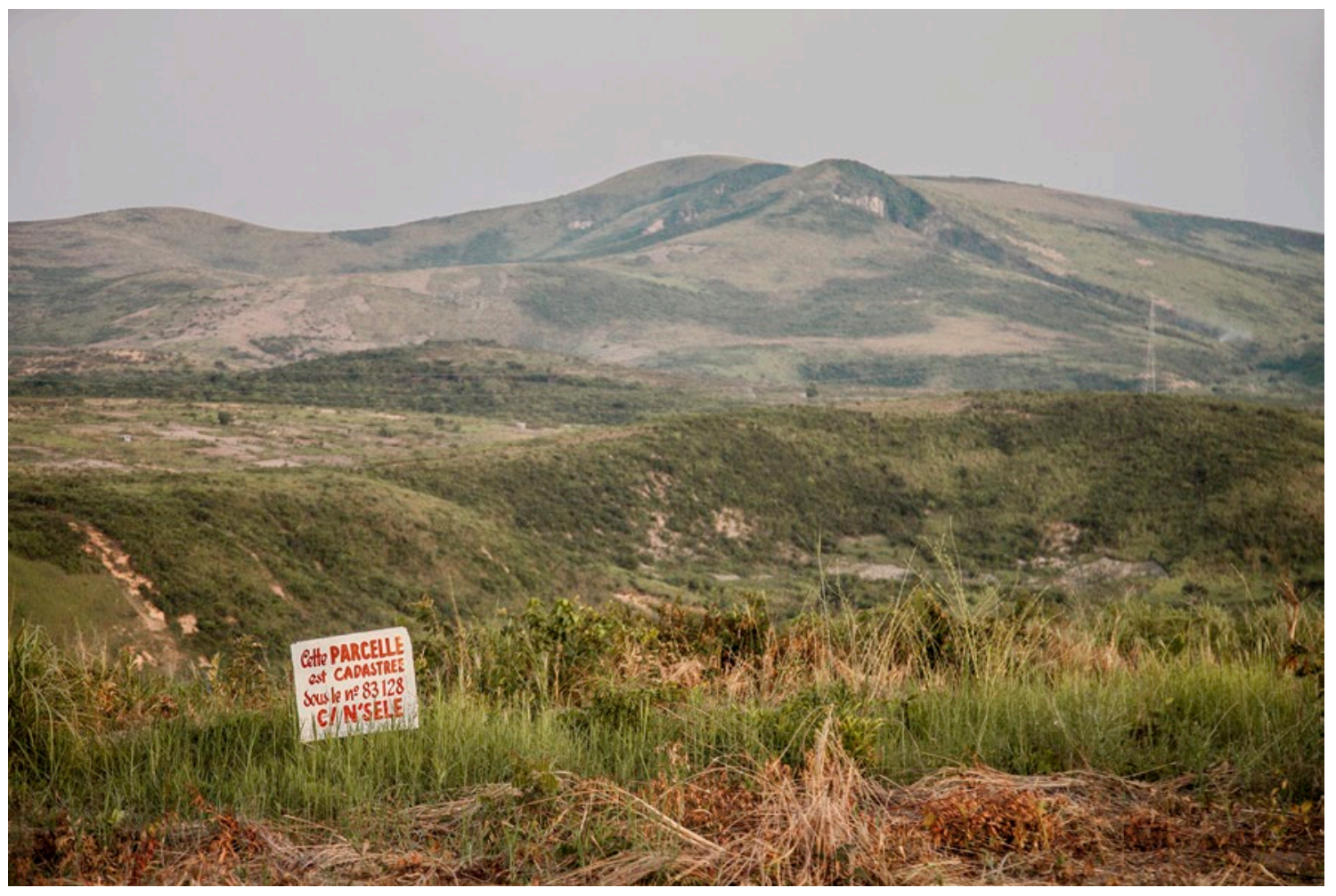

Urban expansion at the foot of Mangengenge mountain, on the eastern outskirts of Kinshasa. 


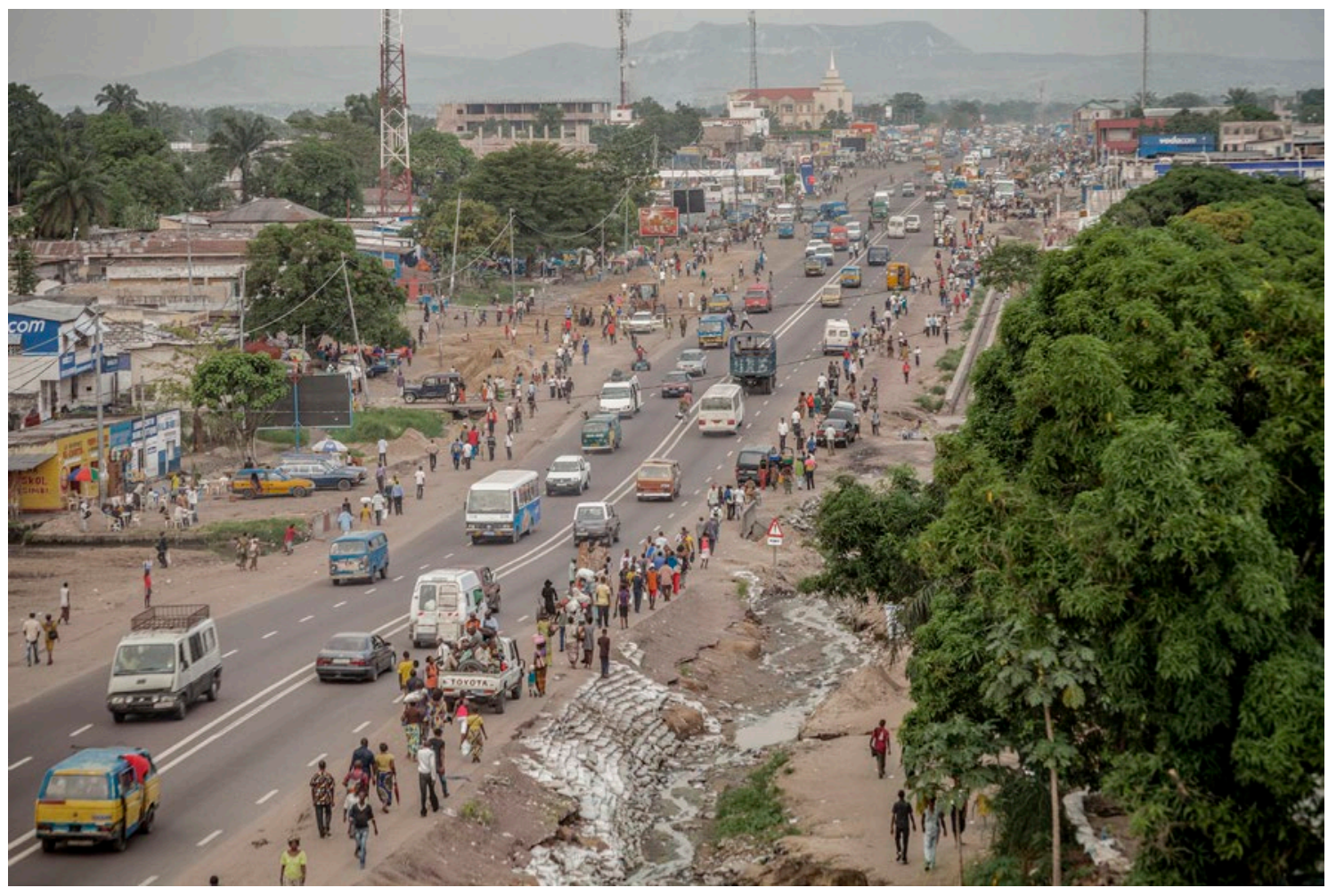

Boulevard Lumumba before its renovation, with Mount Mangengenge in the distance. March 2013 


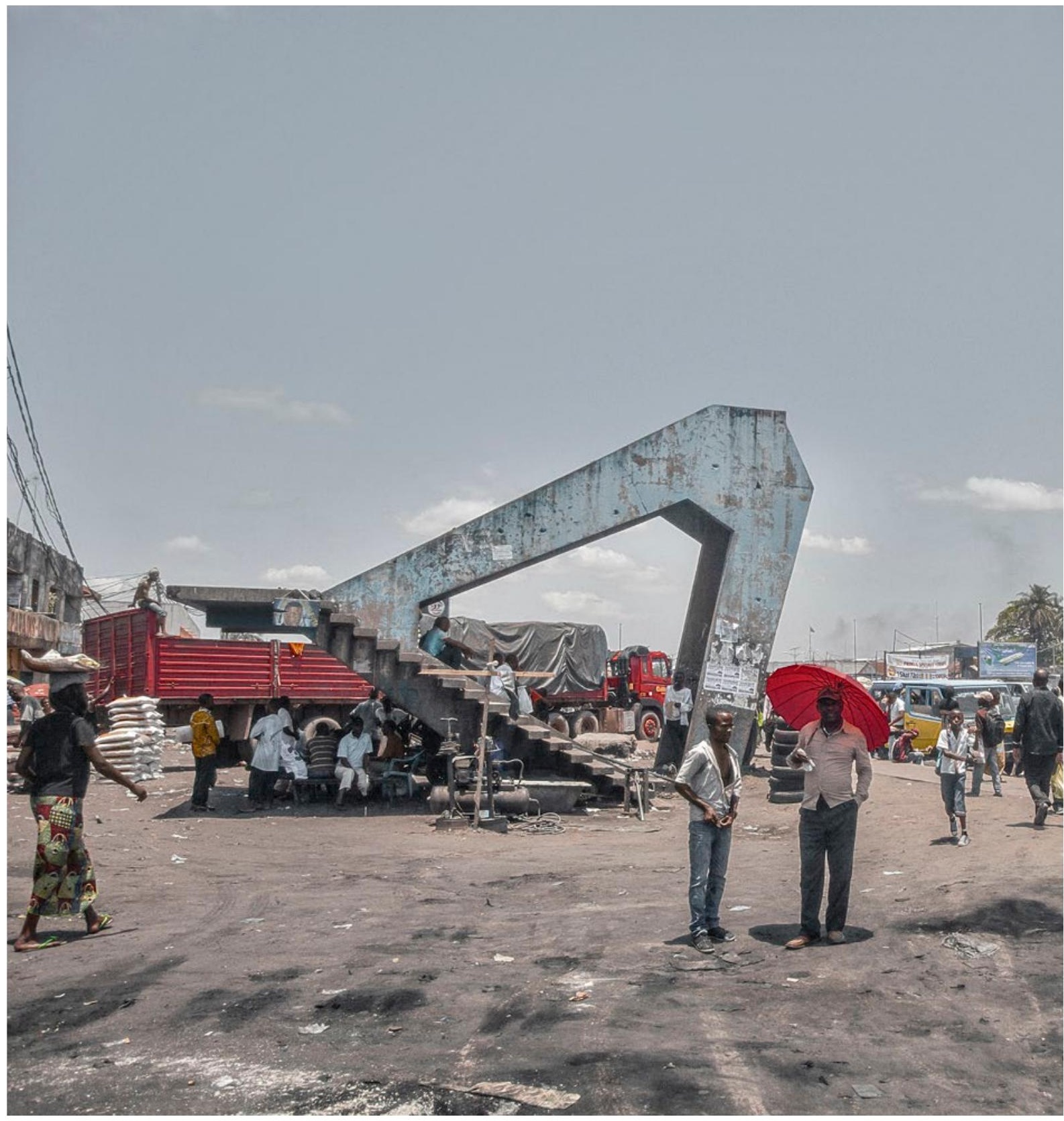

Remains of pedestrian bridge along Boulevard Lumumba, municipality of Masina, Kinshasa 


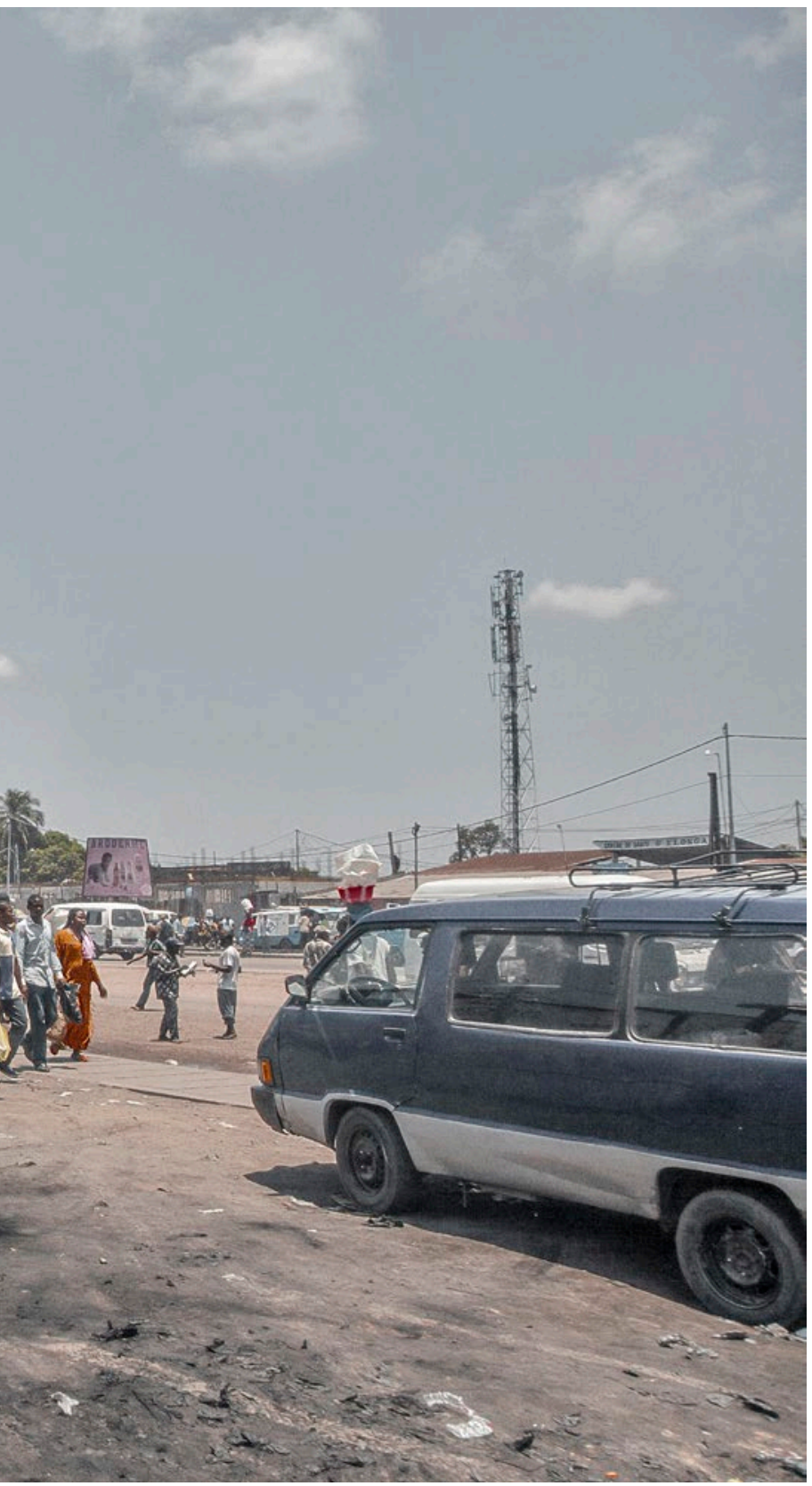




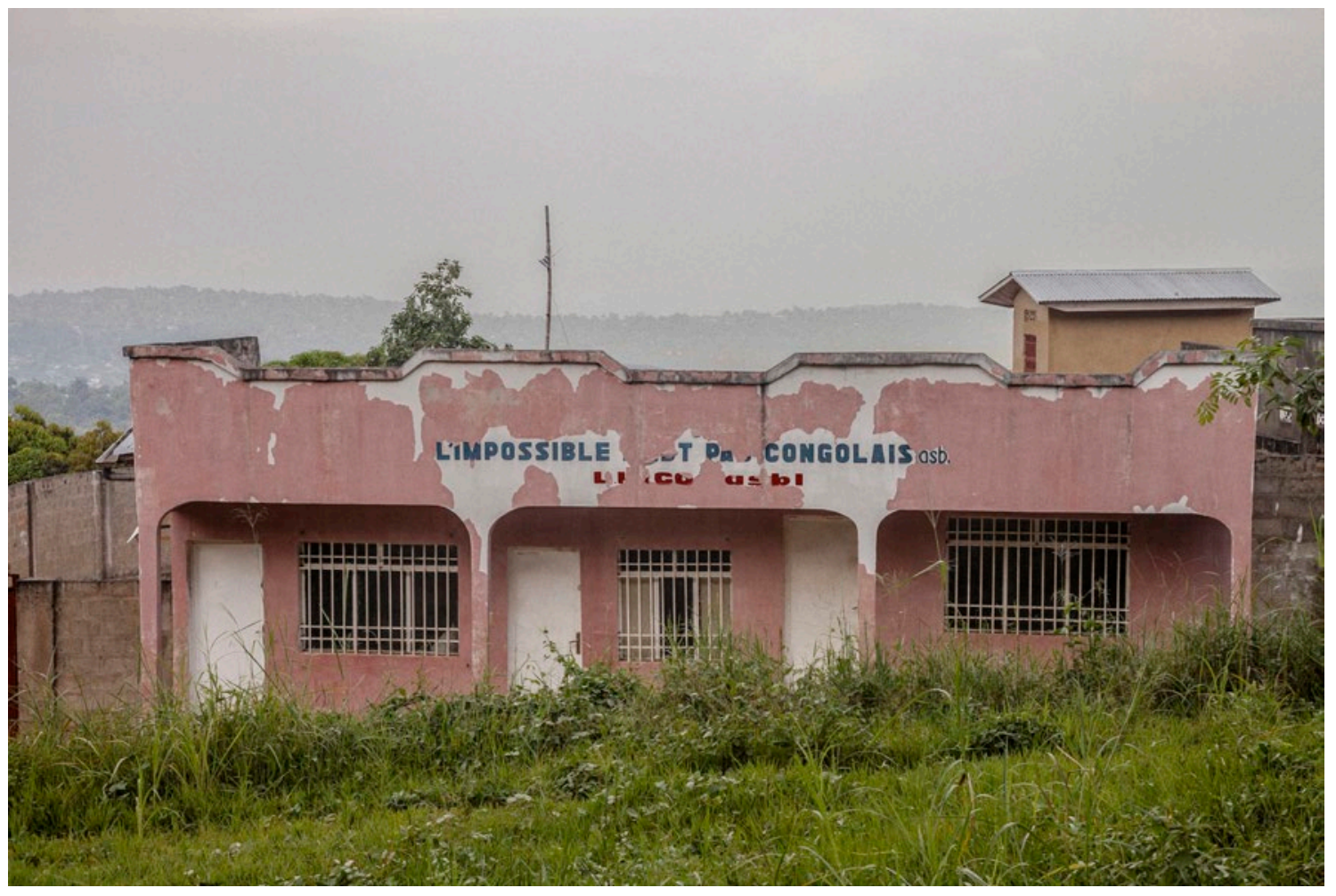

'The impossible is not Congolese', municipality of Lemba, near the campus of the University of Kinshasa (ex-Lovanium). 


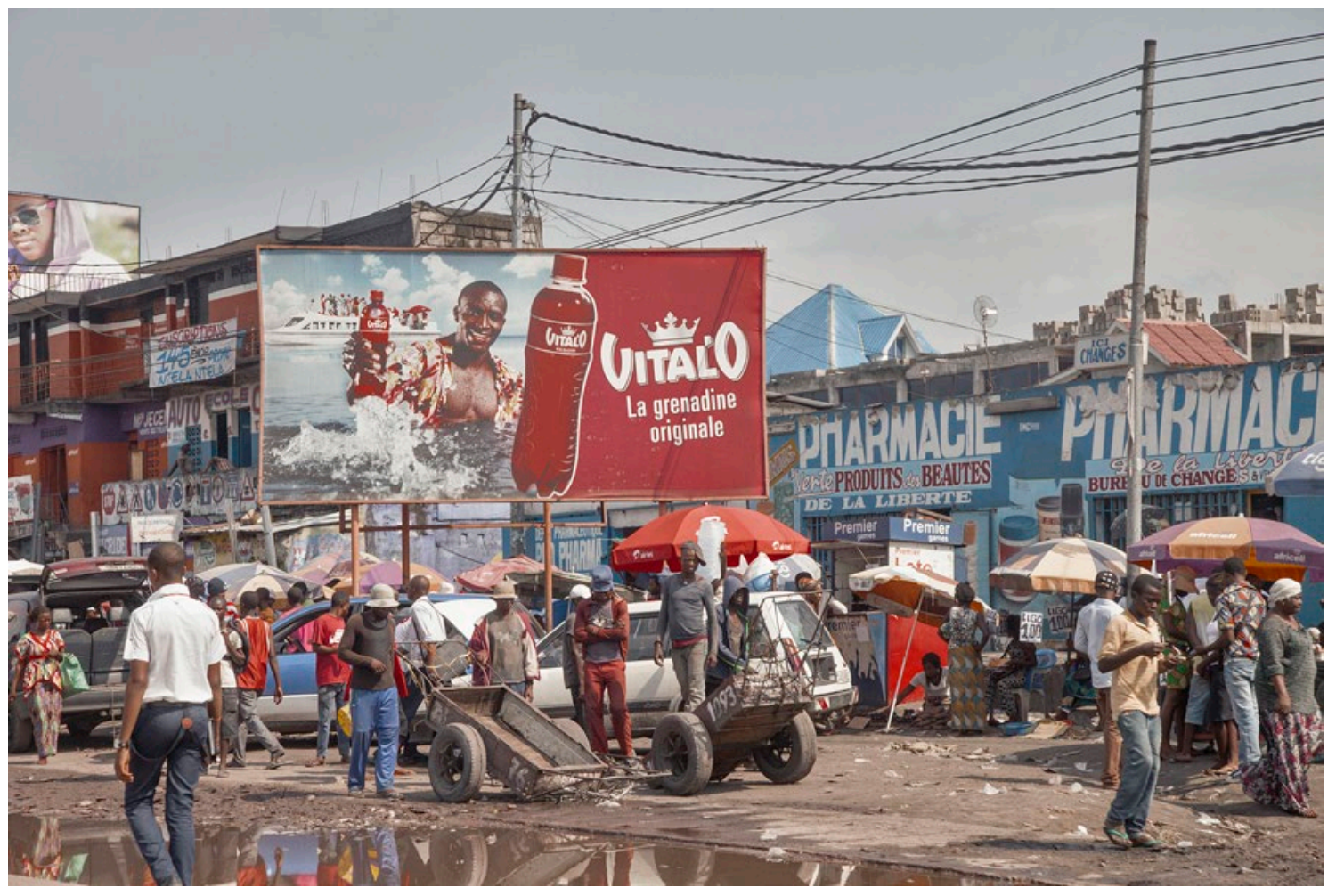

Street view, municipality of Kimbanseke, Kinshasa. 


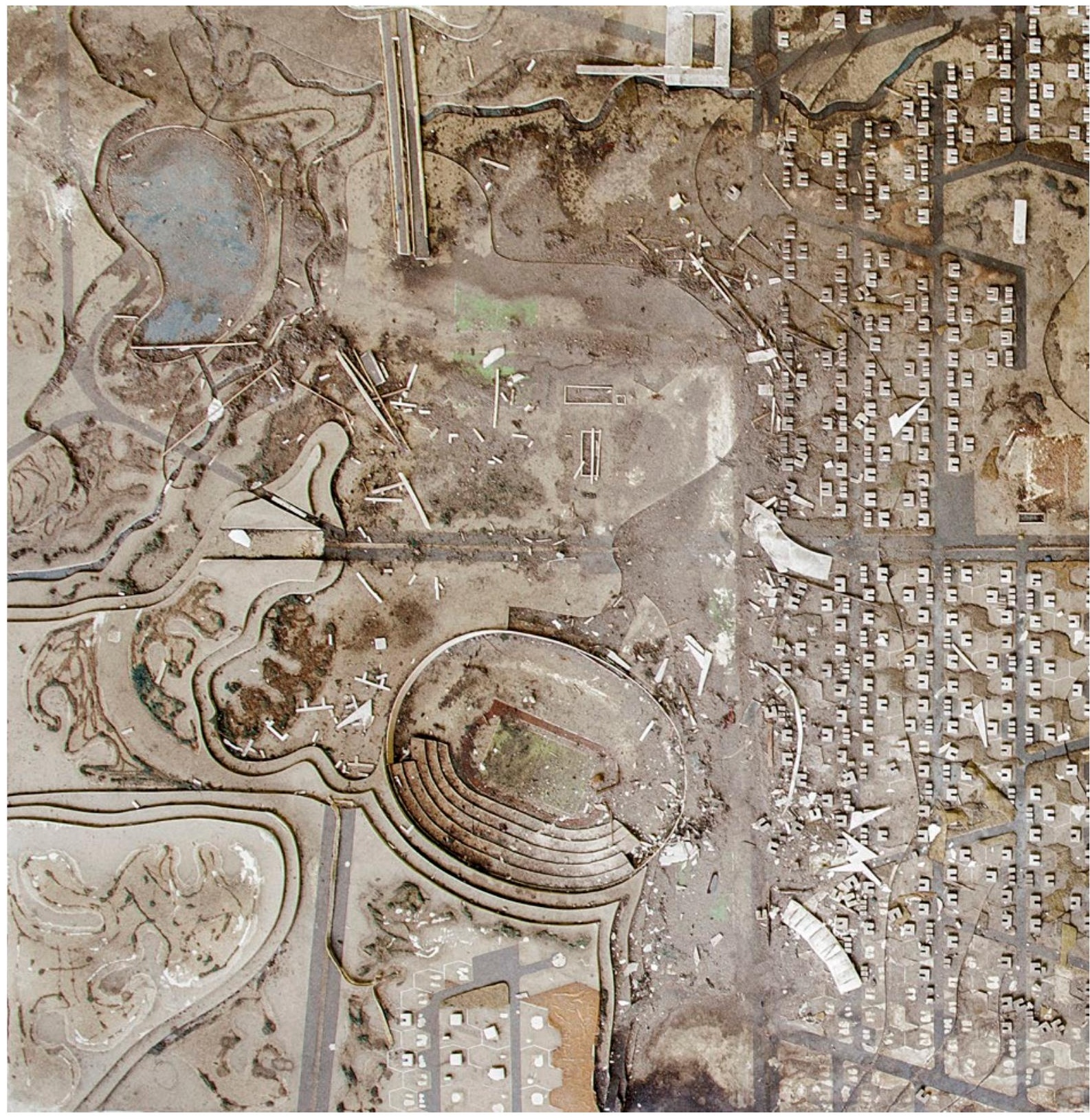

Maquette of Kinkole City, one of the last fully planned zones of Léopoldville. The plan was only partly implemented in the late 1960s and early 1970s. Today the maquette gathers dust in a corridor of the municipal house of Nsele. 


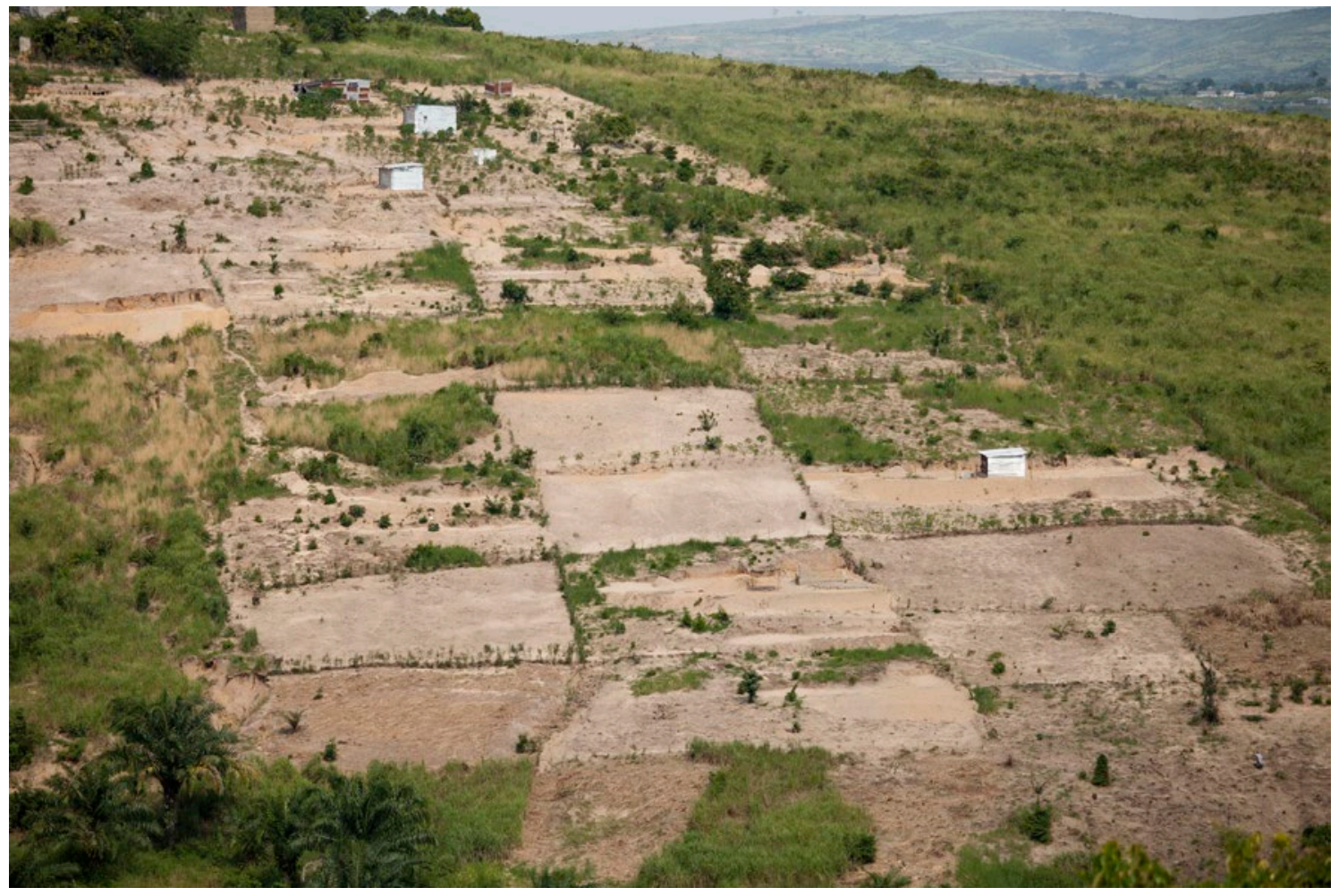

Urban expansion on Kinshasa's southwestern periphery, municipality of Mont Ngafula. 


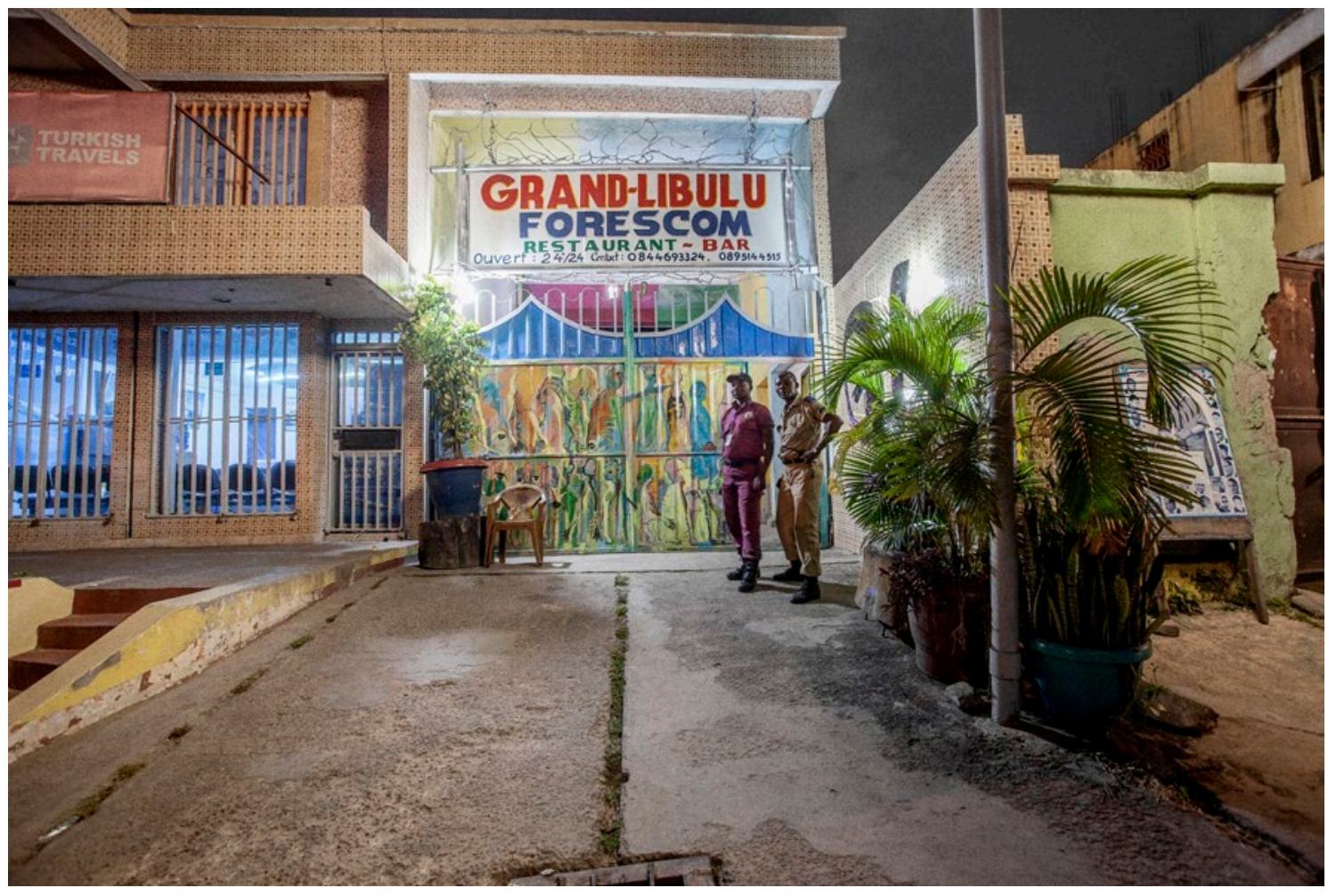

Night club Le Grand Libulu (the Big Hole), Avenue Lieutenant Colonel Lukusa, Rond Point Forescom, municipality of Gombe, Kinshasa. 


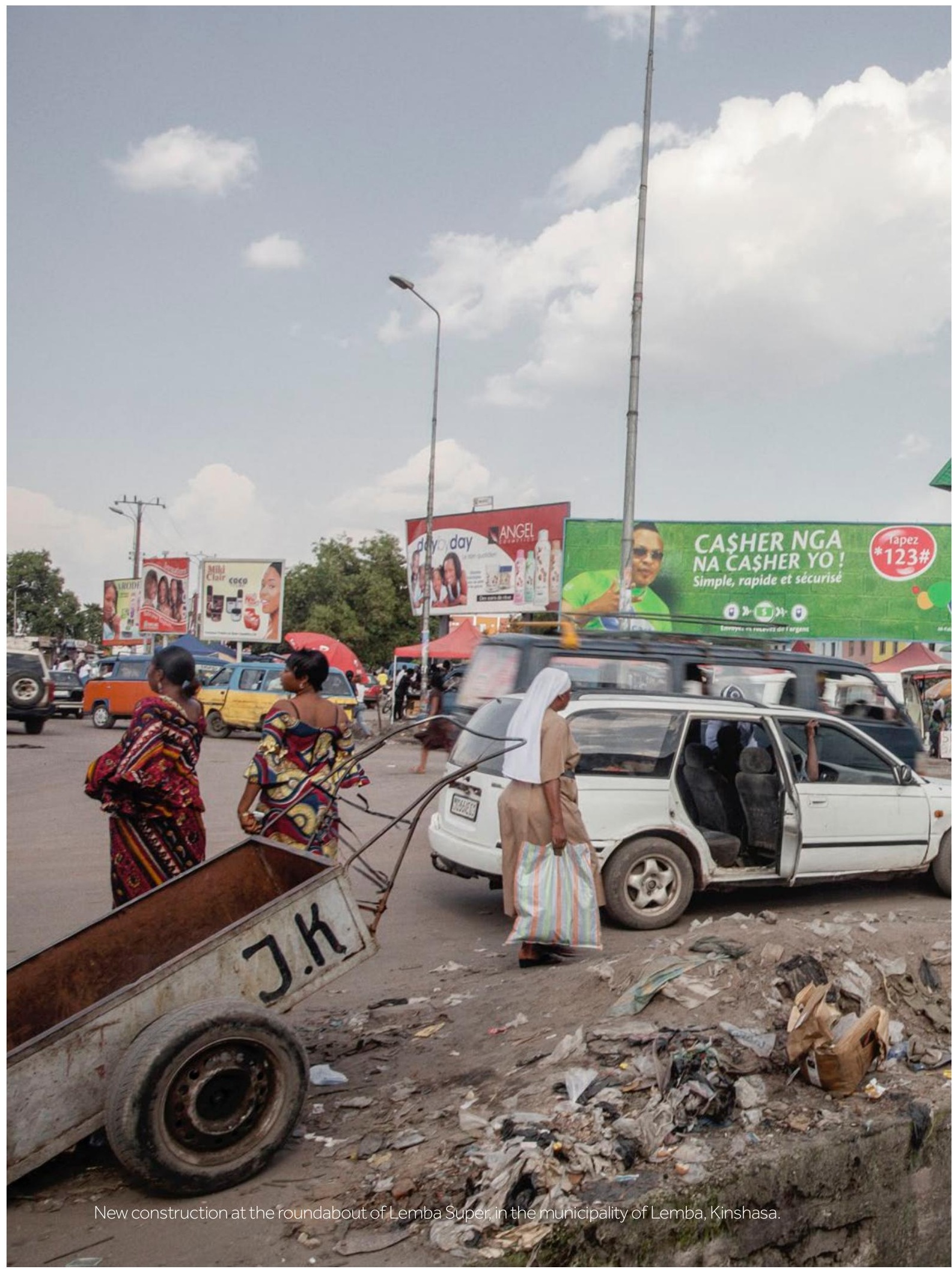




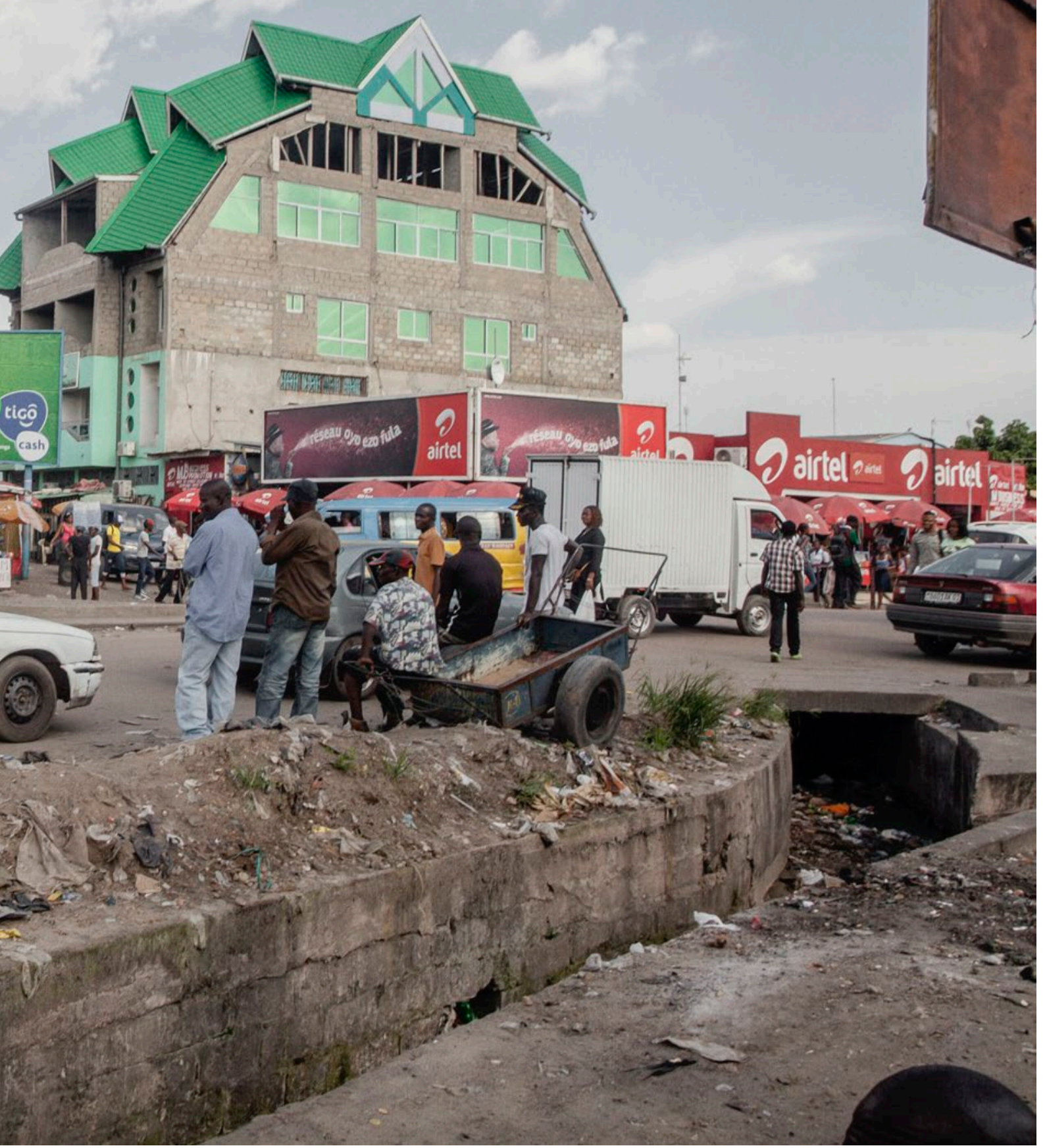




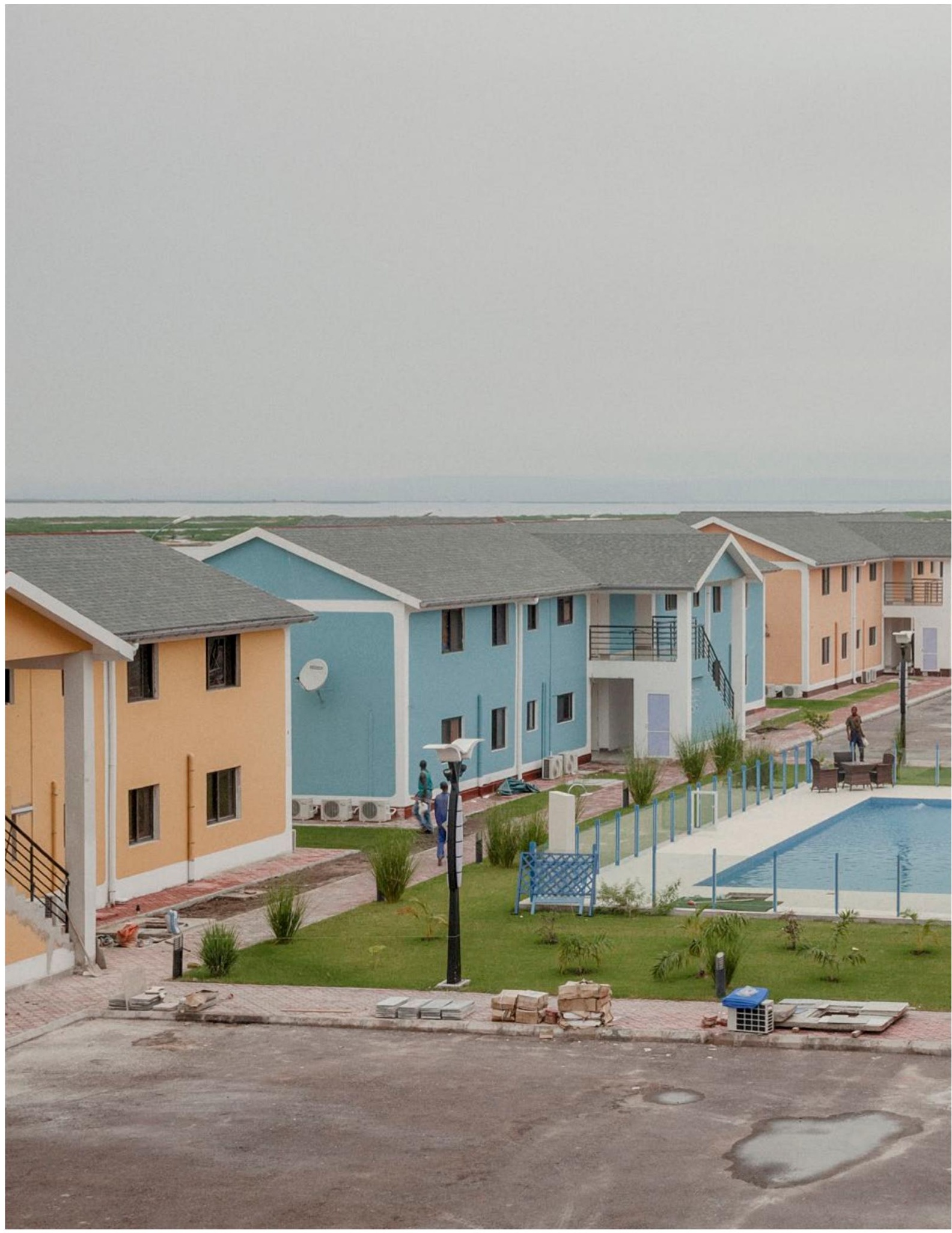




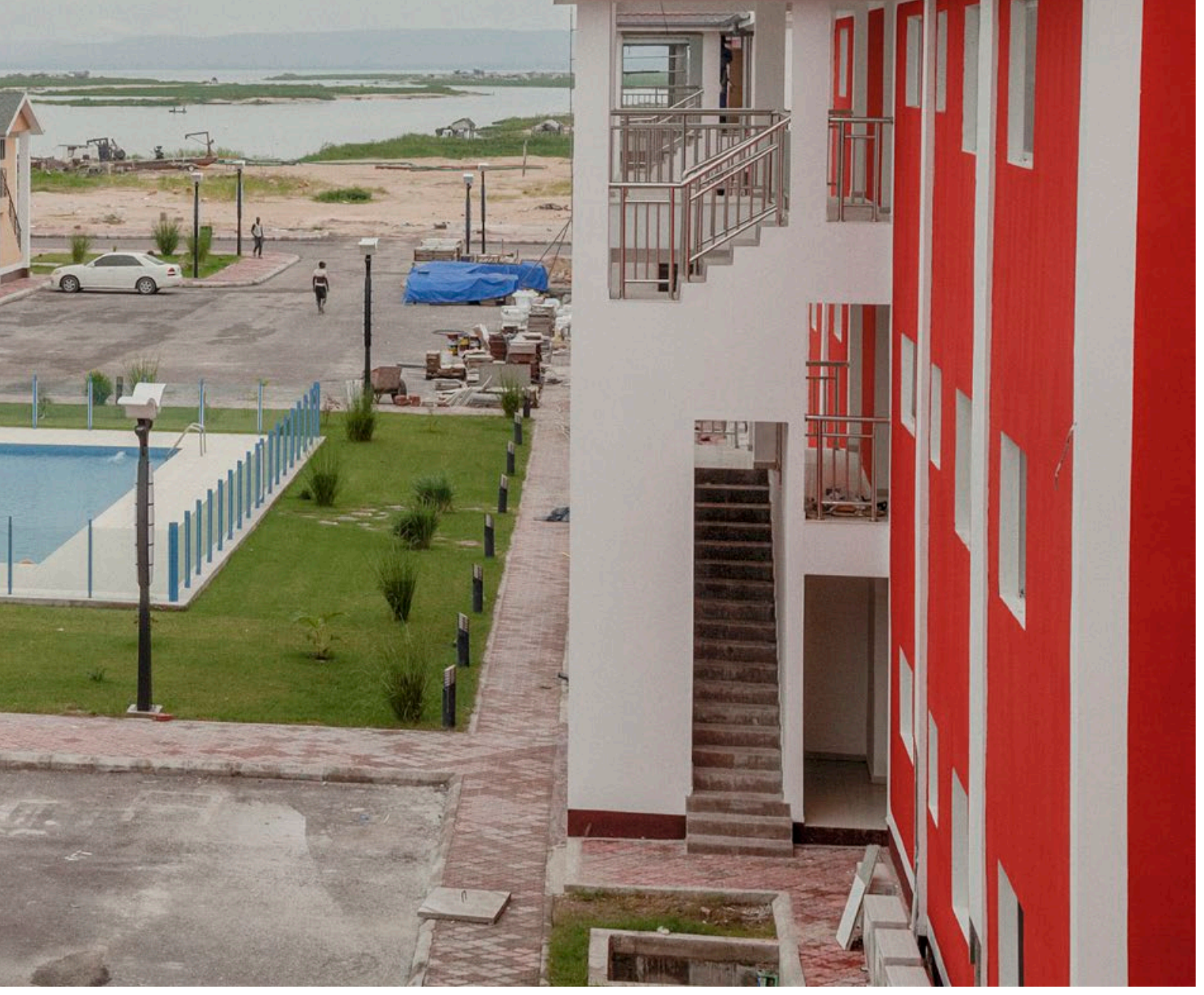




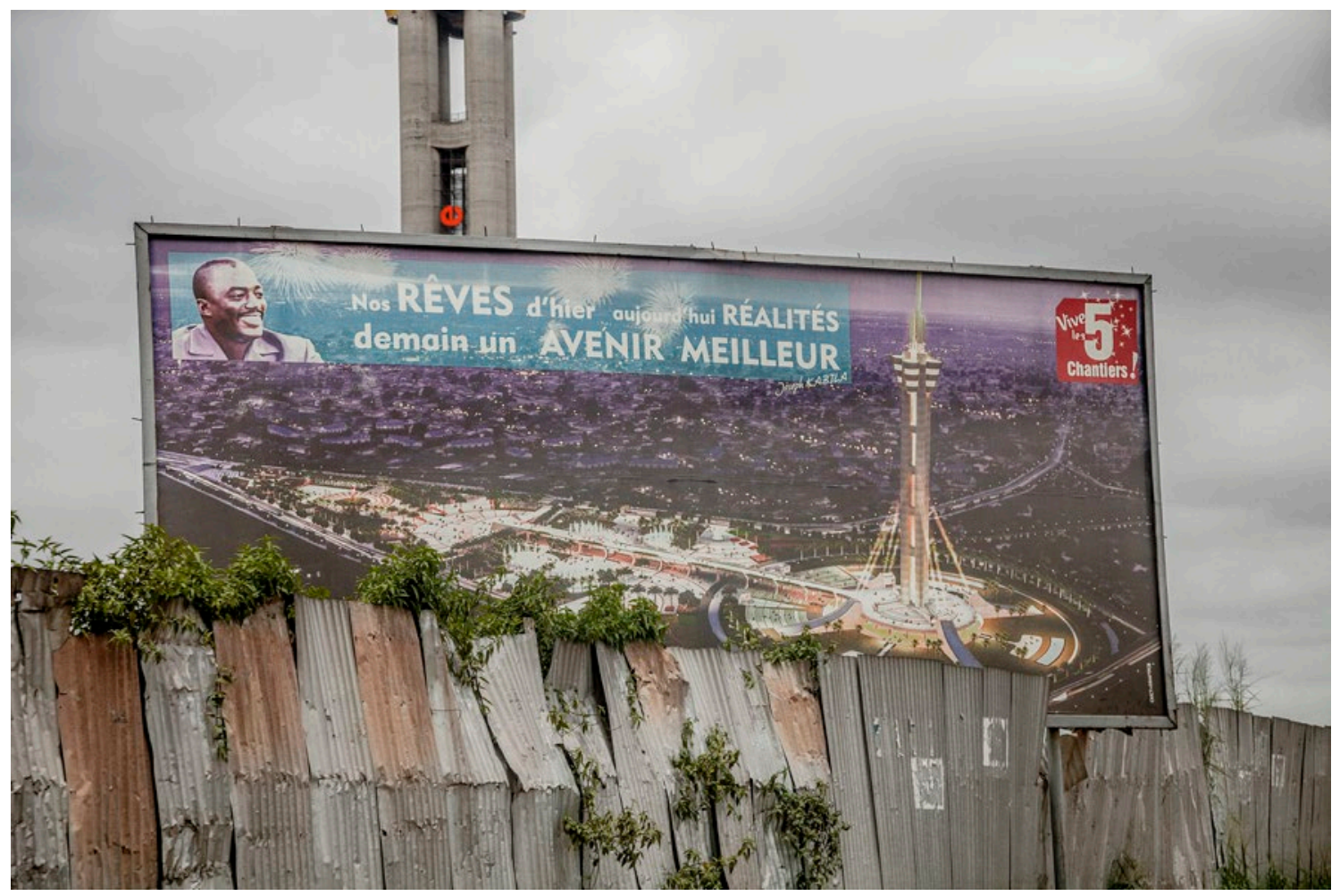

'Our dreams of yesterday, today's realities, tomorrow's be]er future': A 'Cinq Chantiers' billboard advertising the government's infrastructural renewal project (Kabila's '5 Public Works'), Place de l'échangeur, municipality of Limete. 